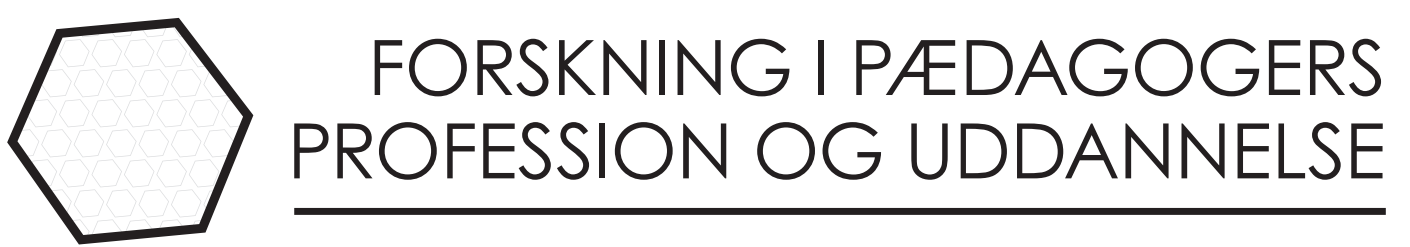

\title{
Kontrolteknologier på sikrede institutioner
}

- anvendelse og betydning i den socialpaedagogiske praksis

\section{Martin Hoffmann}

Ph.d. lektor, Professionshøjskolen Absalon

maho@pha.dk 


\title{
Resumé
}

Denne artikel præsenterer en teoretisk refleksion over og en empirisk analyse af, hvordan vi kan forstå kontrolteknologier i en socialpædagogisk sammenhæng på en sikret institution. Disse kontrolteknologier kan man forstå som særlige organisatoriske hjælpemidler, der har til formål at fremme socialpædagogers kontrol med praksis og børnene. Men i praksis vil vi se, at socialpædagoger hele tiden må forhandle og dømme relevansen af specifikke handlinger i et samarbejde med hinanden og de anbragte børn, for at den socialpædagogiske opgave kan lykkes. Dertil vil artiklen komme nærmere ind på børns oplevelser og engagementer i mødet med disse kontrolteknologiske virkemidler i hverdagen, og hvilke konsekvenser det får for dem.

\begin{abstract}
This article deals with a theoretical reflection on and an empirical analysis of how we can understand control technologies in a social pedagogic context at a secure institution. These control technologies can be understood as special organizational aids aimed at promoting social educators' control of practice and children. However, in practice, we will see that social educators constantly have to negotiate and judge the relevance of specific actions in collaboration with each other and the children who have been placed in order for the social pedagogy task to succeed. In addition to this, the article will take a closer look at children's experiences and engagements in the encounter with these technological tools in everyday life and the consequences it will have for them.
\end{abstract}

\section{Nøgleord}

Sikrede institutioner, anbragte børn, kontrolteknologier, modsætninger, daglig livsførelse, dømmekraft, socialpædagogisk praksis

\section{Keywords}

Secure institutions, Children in care, Control technologies, Contradictions, Conduct of everyday life, Judgement, Social pedagogical practice

\section{Indledning}

I 2018 blev der i Lov om Voksenansvar for anbragte børn og unge pålagt øgede magtbeføjelser til de sikrede institutioner (Børne- og Socialministeriet, 2019). Disse magtbeføjelser er kritiseret fra flere sider, blandt andet fra Børnerådet (Larsen, 2018) og undertegnede i Socialpædagogen (Hoffmann, 2018a). Men hvordan kan vi forstå magtbeføjelser, og hvilken betydning har de for den socialpædagogiske praksis mellem børn og socialpædagoger? 
I denne artikel vil jeg komme nærmere ind på, hvordan disse magtbeføjelser forstået som kontrolteknologiske foranstaltninger (sanktionssystemer, ransagninger, konflikthåndtering osv.) medierer og kan få betydning for hverdagens socialpædagogiske praksis. Artiklen abonnerer på et bredt teknologibegreb, hvor teknologi både henviser til de fysiske artefakter, men også til de tanker og forestillinger, der ligger bag anvendelsen af disse. I artiklen vil vi se empiriske eksempler på, at kontrolteknologiske foranstaltninger (ransagninger, konflikthåndtering mv.) over for børnene sommetider skærper konflikter mellem børn og socialpædagoger, hvor det er vigtigt, at socialpædagoger løbende vurderer og forhandler disse virkemidler i et samarbejde med hinanden og med børnene for at sikre de pædagogiske udviklingsmuligheder. Børnenes engagementer i praksis og deres oplevelse af de kontrolteknologiske foranstaltninger bliver belyst fra et dagligt livsførelsesperspektiv, hvor deltagelse "her og nu" må forstås i forhold til, hvordan denne deltagelse koordineres og tager del i barnets livsførelse på tværs af kontekster (Dreier, 2016, s. 16; Holzkamp, 1998, s. 4). Vi vil se i artiklen, at socialpædagogers håndtering af kontrolaspektet $\mathrm{i}$ anbringelsen (ransagninger) skærper konflikter og udfordrer de pædagogiske udviklingsmuligheder. Eksempelvis når socialpædagoger ransager børns værelser uden deres samtykke, og børnene til modsvar raserer en hel afdeling. Vi vil ligeledes se, at når børn søger at erobre indflydelse på deres livsførelse og går op imod de kontrolteknologiske betingelser, er der potentielle muligheder for, at de skader deres egen sag. Såsom når børn reagerer mod socialpædagogernes kontrol og derved risikerer flere sigtelser under deres anbringelse.

Afslutningsvis viser jeg et konkret empirisk eksempel på, at socialpædagogers tanker og forestillinger om konflikthåndteringer har forandret sig fra hård disciplinering og fysiske magtanvendelser til samtaler med børn om deres adfærd som et pædagogisk anliggende. Men vi ser, at denne involvering i refleksive samtaler kan være vanskelig at realisere i konfliktsituationen.

Det empiriske materiale er indsamlet i forbindelse med Ph.d.-afhandlingen: Pædagogik bag tremmer (Hoffmann, 2018b).

Samlet set er artiklen et bidrag til en diskussion af, hvilke muligheder men også udfordringer der er forbundet med, at socialpædagoger praktiserer kontrol i det socialpædagogiske arbejde under sikrede forhold.

\section{Baggrund - magtbeføjelser på de sikrede institutioner}

Gennem de seneste 20 år har vi set en stigning i brugen af kontrolteknologiske foranstaltninger på sikrede institutioner for anbragte børn. På samfundsplan er børne- og ungdomskriminaliteten faldende (Danske Regioner, 2018). Men de børn, som anbringes på sikrede institutioner, anbringes i stadig stigende grad på baggrund af farligere kriminalitet og mere voldelig adfærd (Ibid.). Senest med vedtagelsen af Lov om bekæmpelse af ungdomskriminalitet i 2018 blev det muligt at anbringe børn ned til 12 år på sikrede institu- 
tioner gennem et nyoprettet ungdomskriminalitetsnævn (Justitsministeriet, 2018). Ligeledes skærpedes de sikrede institutioners magtbeføjelser i henhold til Lov om voksenansvar for anbragte børn og unge, hvor tv-overvågning af fællesarealer og døralarmer blev indført (Børne- og Socialministeriet, 2019). Ser man på viften af kontrolteknologiske foranstaltninger, så dækker de over et meget omfattende niveau: besøgs-, brev-, telefonkontrol, tv-overvågning af fællesarealer, indgreb i den anbragtes adgang til internettet og telefon-, alarm- og pejlesystemer på den enkelte anbragte, døralarmer, alarmknapper, isolation 24 timer ad gangen, aflåsning af værelser om natten, dokumentationssystemer, sanktionssystemer ved brud på husordenen, indespærring om natten, ransagninger mv.. Ovenstående kontrolteknologier henleder ofte opmærksomheden på fysiske genstande og artefakter, der henstår som passive rekvisitter, som kan anvendes af socialpædagoger på ens måder på tværs af institutioner og afdelinger. Men i praksis viser undersøgelser, at disse kontrolteknologier bringes i anvendelse på vidt forskellige måder og medierer praksis på meget forskellig vis, når socialpædagoger både skal kontrollere børnene og samtidig involvere disses selvog medbestemmelse som et pædagogisk anliggende. Derved får de kontrolteknologiske artefakter både betydning for kontrolaspektet, men også for de pædagogiske muligheder med børnene i hverdagen.

\section{Kontrolteknologier og dømmekraft}

De kontrolteknologiske foranstaltninger består med Harold Jack Leavitts organisationsforståelse både af fysiske artefakter som alarmknapper, døralarmer, dokumentationssystemer mv., dvs. organisatoriske hjælpemidler, men også af den viden, som knytter sig til anvendelsen af disse. Eksempelvis forskellige pædagogiske tilgange og metoder (Leavitt, 1965). Forholdet mellem de fysiske kontrolteknologiske hjælpemidler og viden om brugen af disse kan imidlertid ikke adskilles. Når socialpædagoger anvender kontrolteknologiske virkemidler i konflikter med børnene, beror det på situeret viden om den sociale praksis (Dreier, 2008, s. 22; Lave \& Wenger, 2003, s. 142). I forlængelse af dette kan kontrolteknologier med afsæt i kritisk psykologi forstås som samfundsmæssige betingelser, der stiller forskellige muligheder og begrænsninger for socialpædagogernes deltagelse i deres praksis med børnene. I denne forståelse er socialpædagogerne subjekt for deres handlinger, hvilket betyder, at de på den ene side er med til at producere og reproducere de samfundsmæssige betingelser (kontrolteknologierne) for deres arbejde, og på den anden side, på baggrund af de samfundsmæssige krav og nødvendigheder, er bestemt af disse betingelser (Holzkamp, 2013, s. 19- 20). Der er således en dialektisk bevægelse mellem de samfundsmæssige nødvendigheder og krav, og den enkeltes muligheder for i samspil med andre at forme og omforme disse. Derfor kan det eksempelvis godt være, at socialpædagoger har teoretisk viden om, at faste sengetider og indespærring om natten burde skabe forudsigelighed og ro hos børnene. Et helt andet forhold er, hvorledes socialpædagoger individu- 
elt anvender disse kontrolteknologiske virkemidler i socialpædagogisk praksis, og hvordan de forstås og modtages af børnene. Hvor nogle socialpædagoger oplever, at faste sengetider giver anledning til ro og forudsigelighed, så oplever andre, at det giver anledning til voldsomme konflikter med sengestrejke og oprør til følge. Her vil det være den enkelte socialpædagogs erfaringsbaserede fornemmelse for, hvad der virker for hvem, hvornår og hvordan i mødet med børnene. Socialpædagogers forskellige opfattelser af, hvad der virker for hvem, hvornår og hvordan, kan skyldes, at deres muligheder for indgriben i praksis er væsentlig forskellig. Carsten Pedersen skriver med reference til Aristoteles, at vellykket indgriben i praksis skal kobles til gribekraft, som vedrører sprog, karakter og erfaringer og dermed også vores dømmekraft (Pedersen, 2016, s. 101). Socialpædagogers situationsspecifikke erfaringer og dømmekraft vil med dette perspektiv have betydning for, hvad der vurderes som godt at gøre. I den forståelse vil hverken videnskabelig viden (episteme) og produktiv viden og kunnen (techne) i form af "forklaringer" eller specifikke "redskaber" kunne stå alene. Udgangspunktet er sagen, det mellemværende som skal håndteres på etisk og forsvarlig vis i en konkret situation (Pedersen, 2006, s. 70; Pedersen, 2016, s. 101-102).

Selvom det er kendt viden, at socialpædagogers handlinger hænger tæt sammen med den enkeltes individuelle dømmekraft i mødet med børnene, så ser man en stigende interesse for mere ensretning og introduktion af socialpædagogiske metoder i praksis.

\section{Metoder som mirakelkur}

På en sikret institution er der både et element at kontrol/ straf og pædagogik/ behandling, som kan være vanskeligt for socialpædagoger at balancere i hverdagens praksis. Hvad der virker for nogle socialpædagoger, virker ikke nødvendigvis for andre kolleger i samme afdeling. Som nævnt i forrige afsnit skyldes dette, at praktiske handlinger foregår i en konkret situation i et samspil med andre, hvor praktisk handlen er nødvendig. Beslutningen om, hvilken handling der skal udføres, træffes "nu" og "her" og på det grundlag, som er tilstede i den konkrete situation. Handlingen findes ikke på forhånd, men skabes, mens der handles. Det er en individuel timing, fornemmelsen for hvornår det at være afventende eller handle vil være virkningsfuldt og effektivt (Brinkkjær \& Nørholm, 2000). Denne situationsspecifikke udfordring søges løst på forskellig vis i socialpædagogisk praksis. Nogle argumenterer for, at socialpædagoger skal arbejde efter standardiserede pædagogiske metoder som eksempelvis Anger Management, der er en del af CBT - Cognitive Behavioral Therapy. Andre argumenterer for, at socialpædagoger netop skal arbejde differentieret for at imødekomme anbragte børns meget forskellige behov i en kompleks og foranderlig praksis. Og der er undersøgelser, som ligefrem viser, at anbragte børn efterspørger pædagoger, der involverer sig mere personligt end som repræsentant for særlige tilgange og metoder (McKellar \& Andrew, 2013). Ser man tilbage på de seneste 40 - 50 år, er der gjort mange ihær- 
dige forsøg på at finde socialpædagogiske metoder, der kan beskrive og demonstrere, hvad der virker for hvem og hvornår og i hvilken sammenhæng. Disse metoder kan forstås som særlige bestræbelser på at overkomme situationsspecifik viden og standardisere socialpædagogers handlinger i specifikke situationer. Der er tale om en pragmatisk position, hvor fokus er på, hvorledes opgaven kan løses mest effektivt med blik for mål, metode og indhold (Mottelson, 2007, s. 46). Men forskning tyder på, at metoder kan underminere den enkeltes dømmekraft (Buus, Grundahl, Hamilton, Rasmussen, Thomsen og Wiberg, 2012, s. 74-75; Pedersen, 2017, s. 131). Eksempelvis hvor socialpædagoger arbejder metodisk stringent, men overser den situationsspecifikke fintuning i relationen til børnene og derved handler uhensigtsmæssigt. Hvilket i sidste instans kan skade de pædagogiske udviklingsmuligheder, der er hele formålet med anbringelsen.

\section{Teknologier i socialpaedagogisk praksis}

Som jeg har antydet i ovenstående, er der opstået en stigende interesse for introduktion af metoder i den socialpædagogiske praksis. Udviklingen hænger tæt sammen med, at de anbringende myndigheder (kommuner og regioner) har skærpet deres fokus på 'value for money' gennem de senere år. Dette ses eksempelvis i den politiske efterspørgsel på evidensbaserede løsninger på det sociale område (Kildedal \& Krogstrup, 2015, s. 61). Når børn anbringes på en sikret institution, udarbejdes der derfor mål og delmål for barnets udvikling under anbringelsen, så den socialpædagogiske praksis kan rettes mod specifik læring og udvikling hos barnet. Socialpædagoger har derved øget fokus på målstyring i den socialpædagogiske praksis og søger i stigende grad at dokumentere effekterne af deres tilgange og metoder (Christensen m.fl. 2019). Eksempler på disse effekter kunne være: færre magtanvendelser, et fald i recidiv og voldelig adfærd, forbedring af barnets personlige hygiejne, barnets evne til at indgå i sociale relationer mv.

Gennem historien har socialpædagogiske metoder været domineret af psykologiske forestillinger om, hvad der er godt at gøre for anbragte børn (Schwartz, 2014). Disse psykologiske forestillinger kan anskues som teknologier, der søger at styre og regulere socialpædagogers handlinger og praksis på forskellig vis, og som ofte medierer praksis forskelligt fra person til person. På sikrede institutioner kunne dette være ‘Aggression Replacement Training'(ART) som er inspireret af kognitiv og behavioristisk psykologi. Aggression Replacement Training har fokus på børns evne til at ræsonnere moralsk og empatisk, deres selvbeherskelse og kontrol med vredesudbrud. Overordnet set er mulighederne mange, og de psykologiske forståelser forgrener sig i et væld af socialpædagogiske metoder, som i sig selv modificeres, forandres og udvikles på nye måder af de socialpædagoger, der møder de anbragte børn. Disse tankemæssige forståelser af psyken og de fysiske artefakter (organisatoriske hjælpemidler), der skal understøtte en udvikling, former og medierer praksis forskelligt, når de bringes i anvendelse. Derved er 
vi tilbage ved en pointe, som vil blive udfoldet yderligere empirisk og teoretisk i denne artikel. Hverdagen på en sikret institution eksisterer ikke i et vakuum, hvor metoder kan formidles på en neutral og standardiseret måde. Hverdagen formes af de samfundsmæssige forhold, hvor socialpædagoger både skal arbejde kontrollerende/ straffende og samtidig involvere børns selv- og medbestemmelse som et demokratisk og lovgivningsmæssigt anliggende (Hoffmann, 2020). Viden om, hvad der virker for hvem, hvornår og hvordan, beror på den enkeltes (kollektive) dømmekraft og situationsbestemte viden i praksis. Dømmekraft skal derfor tænkes som et kollektivt anliggende, der udfolder sig i den måde, kvaliteten i et samspil foregår på mellem børn og socialpædagoger (Pedersen, 2017, s. 43). Dette kalder almindeligvis på en pluralistisk tilgang, hvor forskellige opfattelser og interesserer integreres og koordineres i et samarbejde om hverdagen. Hvor der forhandles om at få en fælles forståelse af hinandens erfaringer, som ser ud til at være brugbare i en given indsats (Kildedal \& Krogstrup, 2015, s. 67).

\section{Hverdagens modscetninger}

Forholdet mellem kontrol, straf og sanktioner på den ene side, og intentioner om behandling, resocialisering og pædagogik på den anden, har længe været problematiseret inden for traditionel fængselsforskning og i særdeleshed også på sikrede institutioner (Barry \& Moodie, 2008; Bengtsson, 2012; Bonke \& Kofoed, 2001; Bryderup, 2010; Enell, 2016, 2017; Henriksen, 2017; Kyvsgaard, 1998; Pollack, 2009; Rose, 2002; Smith \& Milligan, 2004). Socialpædagoger skal både kontrollere børnene (hvad de må, hvornår og hvordan) gennem anvendelse af kontrolteknologiske foranstaltninger og samtidig skabe betingelser for børns udvikling af deltagelse i praksis (se endvidere Hoffmann, 2018; 2019; 2020). I lov om Voksenansvar for anbragte børn og unge står beskrevet: "... § 7. Magtanvendelse og andre indgreb i selvbestemmelsesretten på anbringelsessteder efter $\S 66$, stk. 1, i lov om social service må kun ske undtagelsesvis og må aldrig erstatte omsorg og socialpædagogisk indsats..." (Børne- og Socialministeriet 2019). Her fremstår hverdagens kontrol (aflåste værelser om natten, besøg, -brev og telefonkontroller, ufravigelige dagsrutiner, sanktioner ved brud på husordenen) som en hård disciplinering, der står i modstrid til de mere bløde idealer om udvikling af børns deltagelse gennem involvering af deres selv- og medbestemmelse i hverdagens praksis. Den socialpædagogiske opgave består dog ikke i at favorisere det ene eller andet. Derimod skal socialpædagoger balancere begge forhold i en kompleks hverdag og forene begge sider $i$ en vanskelig linedans med børnene i et samarbejde. Jævnfør artiklens hovedfokus: Hvordan vi kan forstå kontrolteknologier i en socialpædagogisk sammenhæng på en sikret institution, bliver det muligt i empiriske nedslag at vise de udfordringer, socialpædagoger vil møde i denne balancering af kontrolteknologier og involvering af børnene.

Socialpædagogers håndtering af modsætninger skaber muligheder for konflikter i hverdagens samarbejde om praksis. Både mellem børn og socialpædagoger, 
men også mellem socialpædagogerne. I de følgende empiriske nedslag belyses, hvordan kontrolteknologiske foranstaltninger (sanktionssystemer, ransagninger, konflikthåndtering osv.) medierer og får betydning for hverdagens socialpædagogiske praksis. Analyserne er informeret af en praksisteoretisk- og dialektisk forståelse, hvor (socialpædagogisk)- praksis altid er en modsætningsfyldt sag (Ollmann, 2015), og hvor der er mange perspektiver, som må koordineres i et samarbejde for at få praksis til at fungere (Axel, 2011, s. 61). Det betyder i praksis, at teknologier (såvel tankemæssige forståelser som fysiske artefakter) aldrig kan anvendes på ens måder, men formes forskelligt af de socialpædagoger og børn, som deltager i hverdagens praksis. Dette vil jeg komme nærmere ind på i det følgende.

\section{"Hvis han så noget, så ville han ransage"}

På sikrede institutioner er der regler og retningslinjer for, hvorledes socialpædagoger må udøve magt og håndtere kontrolaspektet $\mathrm{i}$ den anbringende praksis. Socialpædagoger kan eksempelvis foretage kontrol med brevudveksling, telefonsamtaler samt undersøgelse af person eller opholdsrum, hvis det vurderes, at barnet er i besiddelse af effekter, der kan stride mod ordens- og sikkerhedsmæssige hensyn på institutionen (Børne- og Socialministeriet 2019). Men hvordan denne kontrol foretages og på hvilket vidensgrundlag, det beror, som vi vil se i det følgende, på den enkelte socialpædagogs situerede forståelse for praksis og dømmekraft. Der er tale om kontrolmæssige indgreb i barnets privatliv, hvor det kan være vanskeligt for socialpædagogerne at involvere barnets selv- og medbestemmelse. Disse kontrolteknologier (ransagninger) består både af overvejelser over formål og metodiske tilgange og sikkerhedsteknologier (nøgler, fysiske indgreb i den personlige frihed mv.). Når socialpædagoger ransager børns værelser, er begrundelsen, at det medvirker til opretholdelse af institutionens orden og sikkerhed. Men som vi skal se i det følgende, medierer praksis mellem børn og socialpædagoger på uhensigtsmæssige måder, hvor sikkerheden og den daglige orden trues. I et interview på Ismails værelse fortæller han mig:

Ismail: "Du må gøre, hvad du vil herinde, bare du opfører dig ordentligt [...] ellers skal de ikke gå efter mine joints. Man får sådan et had til dem. Når jeg står op i morgen, vil jeg smadre afdelingen. Det er det eneste, man kan gøre herinde. Det er ikke noget voerd, han har fundet vores joint. En på [en sikret institution] han tikkede hele tiden. Hvis han så noget, så ville han ransage. Hver gang han fandt det, smadrede vi hele afdelingen. Alle gik helt amok. Det har altid undret mig. Du ved, afdelingen bliver smadret, hvorfor gør du det her? Så ødelagde man ting, tegnede på voeggene og kaldte dem fucking ludere, to uger for han kom, var folk glade, de havde det godt. Der var ingen, der irriterede folk [...] Drengene vil aldrig stole på ham. Vi er allesammen kriminelle. Vi ryger vores joints, og så passer vi os selv. Men tager de jointen, flipper de ud. Det forklarede jeg dem også [...] Vi var tre, der smadrede hele afdelingen. Alt maden blev smidt ud, vi smadrede alle glas. Alle møbler blev smadret og knust. Det gik ud over alle, at ham den nye tog hashen fra os" (Hoffmann, 2018). 
I ovenstående interviewpassage ser vi, at ransagninger er en magtfuld kontrolteknologi, der bredt set kan anvendes af socialpædagoger til at indfri og opretholde lovgivnings- og husordensmæssige regler på institutionen. I dette tilfælde besiddelse af euforiserende stoffer. Det er en samfundsmæssig praksis, hvor socialpædagoger søger at løse overordnede formelle krav, som kommer udefra, og som får betydning for deres indbyrdes relationer indenfor på institutionen. Men hvorvidt, hvornår og på hvilken baggrund, der skal ransages, beror på den enkelte socialpædagogs dømmekraft i mødet med børnene. Der er, trods politiske bestræbelser efter at skabe ensretning gennem socialpædagogiske metoder, en menneskelig og personlig involvering, der udfordrer disse bestræbelser. Det kan vi eksempelvis se i Ismails beskrivelse af den "nye" socialpædagog, som håndterer anbringelsen og sanktionssystemerne anderledes end kollegerne. Den enkelte socialpædagogs fintuning og fornemmelse for, hvad der virker i praksis, kan være en særlig styrke i den socialpædagogiske praksis, men kan samtidig udfordre kontinuitet og fælles løsninger i en personalegruppe. På en sikret institution er der både et element af kontrol og samtidig en samfundsmæssig forventning om pædagogik, hvor børns selv- og medbestemmelse skal involveres. Som vi kan se i eksemplet, er det vanskeligt for socialpædagogerne både at indfri lovgivningsmæssige forhold (fjerne illegale genstande) og samtidig involvere børnenes medbestemmelse som et demokratisk og pædagogisk anliggende i et fælles samarbejde mellem dem. Socialpædagogens håndtering af kontrolteknologien (ransagningen) foretages på en måde, hvor kontrolaspektet overtager i relationen, og hvor børnenes perspektiver udebliver. Når samarbejdet mellem børn og socialpædagoger udebliver, medieres praksis på en uhensigtsmæssig måde, hvor børnene søger at gå op imod de kontrollerende sammenhænge for at skabe medindflydelse. Og hvor børnene som i eksemplet kan skade deres egen sag med yderligere strafforanstaltninger og kontrol til følge.

Socialpædagogers fornemmelse for, hvornår og hvordan kontrolteknologier skal anvendes i praksis, skal vi se nærmere på i det næste eksempel. Her skal vi se, at socialpædagogers kontrol med børnene og den pædagogiske håndtering af konflikter med dem knytter sig til forestillinger om børnenes problemer. Socialpædagogens dømmekraft og vurdering af, hvorledes anbringelsens modsætning skal håndteres gennem anvendelse af kontrolteknologier, er derved forbundet til tanker om børns problemer og deres udviklingsmuligheder i praksis.

\section{"Når de smadrer det hele. Så går jeg bare stille og roligt rundt"}

Der har historisk og samfundsmæssigt altid eksisteret en anseelig debat om den pædagogiske behandling af anbragte børn på døgninstitutioner. Behandlingstankerne forandrer sig løbende med socialpædagogikkens historie og udviklingen i det samfund, den udøves i. Mette Frederiksens undskyldningstale til Godhavnsdrengene og andre børnehjemsbørn den 13. august 2019 i Statsministeriet er et udmærket eksempel herpå (Frederiksen, 2019). Kritikken af korporlig afstraffelse 
i konflikter med anbragte børn startede i 1950'erne og er i dag udskiftet med mere bløde forestillinger om pædagogik, medbestemmelse og udvikling af børns deltagelse gennem involvering (Øgendahl, 2000). I dag, 70 år senere, står den socialpædagogiske debat et nyt sted. Fysiske magtanvendelser dvs. indgreb i barnets selvbestemmelsesret er en del af hverdagen, men socialpædagoger søger at undgå magtanvendelser gennem risikovurderinger og refleksive samtaler med børnene før, under og efter konflikter (Ankestyrelsen, 2018). I samtalen med pædagogen Louise skal vi se, at hendes dømmekraft i risikovurdering af konfliktsituationer med børnene bygger på tanker om børns ressourcer og udviklingsmuligheder.

Louise: "Når de (de unge) smadrer det hele. Så går jeg bare stille og roligt rundt. Så fejer jeg det bare lidt til side og tager det stille og roligt"

Martin: "Hvad er det egentlig, som scetter sådan en situation $i$ gang, at de unge kan finde på at smadre det hele? Hvad forestiller du dig, det handler om?"

Louise: "Nogle gange, så handler det om, at de egentlig har svort ved at tcenke loengere $u d$. Der er nogle ting, som er svoere at rumme og den tankercekke, vi andre kan lave inde $i$ hovedet - jeg gør sådan, og der sker det og det, så finder jeg ud af, hvad jeg så skal stille op. Den tankercekke eksisterer ofte ikke, deres evne til at reflektere er [...] rimeligt begrcenset. Og så er der nogle situationer, når man ikke forstår det. Det er lidt det som små børn, der kan blive stikhysteriske, fordi de simpelthen ikke forstår, når man står der og siger det samme igen og igen og igen. Men de forstår ikke, hvad det er, at man står og siger, og bliver bare mere og mere frustreret. Sådan tror jeg også, at de unge har det her. Du bliver ved at sige, at de skal opføre sig ordentligt, og de siger, jamen jeg opforer mig ordentligt. Jeg gør det bedste, som jeg har laert. Hvad mener du, når du siger opfør dig ordentligt de kan måske ikke satte ord på, hvad mener du, når du siger opføre dig ordentligt. De bliver frustreret over at få at vide, at de skal opfore sig ordentligt, men ikke ved hvad det betyder" [...] Før i tiden lagde vi dem jo ned. Der lavede man en magtanvendelse. Det gør man for så vidt muligt ikke mere. Så loenge det er materielle ting, så må det vore det. Jeg arbejder med poedagogik $i$ døgnafsnittet, som ligger meget godt $i$ tråd med det, som man også er begyndt at indføre $i$ undervisningscentret, hvor det er, at man venter. Man skal smede, imens jernet det er koldt, ved at sige, der er ikke nogen ide $i$ at begynde at diskutere med en ung, som hoenger helt oppe under loftet. Det kommer kun til at gå en vej, og det er endnu voerre. Men $i$ stedet vente til at de har raset ud, og så dagen efter tage en snak med den unge. Hvad gik det her egentligt ud på? (Hoffmann, 2018).

Som jeg har beskrevet indledningsvist, kan socialpædagogers arbejde opfattes som en samfundsmæssig praksis. Socialpædagogers praksis formes af de samfundsmæssige nødvendigheder og krav om kontrol med børnene, og samtidig er de med til at forme og omforme disse kontrolteknologiske betingelser i et samarbejde. Denne samfundsmæssige praksis og de forestillinger, som danner baggrund for handlinger (om hvad man bør og ikke bør gøre), er i udvikling og forandres i takt med de mennesker, som er involveret heri. De involverede personer er både politikere, socialpædagoger og forskere. Men også andre relaterede faggrupper som eksempelvis psykologer, socialrådgivere, tilsynsmyndigheder mv. Hvor der tidligere var kritik af socialpædagogers korporlige afstraffelse af børn, så står den kritik et andet sted i dag. I dag kritiseres brugen af magtanvendelser og andre 
former for indgreb i børns selvbestemmelsesret. Derfor skal alle magtanvendelser indberettes og begrundes til myndigheder uden for institutionerne. I hverdagens praksis kan vi se, at Louise netop forholder sig til denne historiske udvikling og hvilken betydning, det får for hende, når hun skal løse konfliktsituationer med børn, der smadrer det hele. Trods politisk bevågenhed på mere ensretning og socialpædagogiske metoder, så ser vi her i dette eksempel den individuelle og kollektive fornemmelse for, hvad der virker og ikke virker i mødet med børnene. Louise referer ikke til særlige tilgange og metoder, når hun skal forklare, hvordan hun møder børn, der skaber konflikter. Hun refererer derimod tilbage til kollegialt forhandlede tilgange fra undervisningscentret, hvor man "smeder, imens jernet det er koldt". Her viser Louise os, at det netop er, når børnene er faldet til ro, at de kan inviteres ind i et samarbejde i refleksive samtaler. Og hvor hårde konfrontationer kan ødelægge de pædagogiske udviklingsmuligheder med børnene.

Dertil beskriver Louise, hvordan det socialpædagogiske arbejde tidligere bestod af afretning og disciplinering. Men at disse forestillinger i dag er udskiftet med selvudvikling gennem refleksive samtaler. Denne selvudvikling kræver, at børnene inviteres ind som aktive deltagere i udviklingen. Louises invitation til refleksive samtaler med udadreagerende børn viser, at forandringen i forestillingerne om udsatte børns behov, ressourcer og udviklingsmuligheder har betydning for den socialpædagogiske indsats med børnene under indespærring. Hvor netop et samarbejde mellem socialpædagoger og børn er påkrævet, for at mere bløde idealer om pædagogik, selv- og medbestemmelse og involvering af børn som aktive deltagere kan lykkes.

\section{Afsluttende opsamling}

Denne artikel har beskæftiget sig med en teoretisk refleksion over og en empirisk analyse af, hvordan vi kan forstå kontrolteknologier i en socialpædagogisk sammenhæng på en sikret institution. Herunder hvordan kontrolteknologiske foranstaltninger medierer praksis, når socialpædagoger bringer disse i anvendelse på forskellig vis. Gennem to empiriske nedslag ser vi, at kontrolteknologier håndteres væsentligt forskelligt af socialpædagogerne og giver meget forskellige udslag for de pædagogiske muligheder. I det første empiriske nedslag viser jeg, at de kontrolteknologiske foranstaltninger i en ransagning kan håndteres som en stram styring og kontrol med børnene. Socialpædagogens håndtering af ransagninger bygger på hans personlige dømmekraft og udfordrer relationen mellem børn og socialpædagoger. Samfundsmæssige krav om, hvad anbragte børn må være i besiddelse af eller ej, kan håndteres på mange måder. I det empiriske nedslag kan vi dog se, at socialpædagogen håndterer ransagninger på en måde, som skader de langsigtede muligheder for pædagogisk arbejde med børnene. I det andet empiriske nedslag viser jeg, i modsætning til det første, at Louises håndtering af ro og orden på institutionen kan bygge på kollegialt forhandlede tilgange, der understøtter hendes dømmekraft. Hvor det første empiriske eksempel viser, 
at kontrollen kan håndteres på en nedbrydende måde for relationen mellem børn og socialpædagoger, viser eksempel to, at der kan være mere langsigtede pædagogiske perspektiver, der skal medtænkes, når der løses konflikter. Eksempelvis hvor Louise fejer til side med et langsigtet relationelt blik på refleksive samtaler. Som vi kan se i de to empiriske nedslag, guider og vejleder kontrolteknologier ikke socialpædagogers handlinger på en neutral måde. De medierer praksis forskelligt og beror på den enkelte socialpædagogs situerede viden om og dømmekraft i praksis i samspil med de involverede heri. Socialpædagoger kan derved ikke styre og regulere praksis alene ved hjælp af kontrolteknologier. De skal håndteres på en dialogisk og tænksom måde i et samarbejde mellem børn og socialpædagoger, hvis den socialpædagogiske opgave skal lykkes.

\section{Litteratur}

Ankestyrelsen (Maj 2018) Pædagogisk praksis på de sikrede døgninstitutioner. Ankestyrelsen.

Aristoteles (2000). Etikken. Frederiksberg. Det Lille Forlag.

Axel, E. (2011). Conflictual Cooperation. Nordic Psychology, 63, 56-78.

Barry, M. \& Moodie, K. (2008). This isn't the road I want to go down: Young people's experiences of secure care. Glasgow: Who Cares? Scotland.

Bengtsson, T. (2012). Youth behind bars: An ethnographic study of youth confined in secure care institutions in Denmark. University of Copenhagen.

Berliner, P., Feldman, M., Hejazi, F., Lundby, G (2009). Fortællinger om foretrukket identitet: narrativt perspektiv på intervention I Bro, K., Løw, O., \& Svanholt, J. A. (2009). Psykologiske perspektiver på intervention i pædagogiske kontekster. København: Dansk Psykologisk Forlag.

Bonke, J., \& Kofoed, L. (2001). Længervarende behandling af børn og unge i sikrede pladser - en evaluering. København: Socialforskningsinstituttet.

Brinkkjær, U \& Nørholm, M (2000). Hvorfor er det så svært at omsætte teori til praktik I Olsesen, S. G (2000) Pædagogiske praktikker. Pædagogisk Udviklingscenter. Viborg Seminariet.

Bro, K., Løw, O., \& Svanholt, J. A. (2009). Psykologiske perspektiver på intervention i pædagogiske kontekster. København: Dansk Psykologisk Forlag.

Bryderup, I. (2010). Ungdomskriminalitet, socialpolitik og socialpædagogik: biografiske interview med unge om straf og behandling. KLIM.

Buus, A. M., Grundahl, T. H., Hamilton, S. P., Rasmussen, P., Thomasen, U. N. \& Wiberg, M. (2012). Brug af evidensbaserede metoder i seks pædagogiske institutioner. Når evidens møder den pædagogiske hverdag, rapport 3, august 2012. Aalborg: Aalborg Universitet, Institut for Læring og Filosofi.

Børne- og Socialministeriet. (2019). Bekendtgørelse af lov om voksenansvar for anbragte børn og unge jf. lovbekendtgørelse nr. 178 af 26. februar 2019

Christensen, G. (2002). Psykologiens videnskabsteori - en introduktion. Roskilde: Roskilde Universitetsforlag. Sider 236.

Christensen M., Sprogøe J., Aagerup L. Hoffmann M. \& Andersen R, (2019). Dokumentation med mening i socialpædagogisk arbejde, (Professionshøjskolen Absalon juni 2019)

Danske Regioner (2018). Den årlige statistik på de sikrede institutioner. København: Danske Regioner.

Dreier, O (2008). Psykotherapy in Everyday Life. New York. Cambridge University Press.

Dreier, O. (2016). Conduct of everyday life: Implications for Critical

Psychology. In Schraube, E., \& Højholt, C. (Eds.), Psychology and the conduct of everyday life (pp. 15-33). New York: Routledge. 
Enell, S. (2016). Young people in limbo: perceptions of self- presentations when being assessed in secure accommodation. Nordic Social Work Research, 6(1), 22-37.

Enell, S. (2017). 'I got to know myself better, my failings and fault': Young people's understandings of being assessed in secure accommodation. Nordic Journal of Youth Research, 25(2), 124-140.

Fleischer, V. A (2009) Om hjerne, miljø og adfærd I Bro, K., Løw, O., \& Svanholt, J. A. (2009). Psykologiske perspektiver på intervention i pædagogiske kontekster. København: Dansk Psykologisk Forlag.

Frederiksen, M (2019). Statsminister Mette Frederiksens tale ved arrangement for Godhavnsdrengene og andre børnehjemsbørn den 13. august 2019. https://www.stm.dk/_p_14843.html

Henriksen, A.-K. (2017). Confined to Care: Girls' Gendered Vulnerabilities in Secure Institutions. Young, 26(5), 1-17.

Hilling, S. (2003). Kognitiv Stil. Århus: Systime Akademic

Hoffmann, M (2018a). I Rørbæk, M (1. oktober 2018) Forsker advarer mod mere magt. Socialpædagogerne. https://socialpaedagogen.sl.dk/arkiv/2018/10/forsker-advarer-mod-mere-magt/

Hoffmann, M. (2018b). Pædagogik bag tremmer - unges hverdagsliv på en sikret institution mellem bestræbelser om kontrol og pædagogiske intentioner om forandring. Ph.d.-afhandling.

Roskilde: Ph.d.-skolen for mennesker og teknologi, Roskilde Universitet.

Hoffmann, M (2019). Anbragte børn i Socialpædagogiske lænker. Nr 2. 2019. Nordisk Udkast.

Hoffmann, M (2020). Børns ret til selv- og medbestemmelse på sikrede institutioner I Jacobsen, F. A \& Hestbæk, A. D (2020). Børns rettigheder - i socialfagligt perspektiv.

Holzkamp, K. (1998). Daglig livsførelse som subjektvidenskabeligt grundkoncept. Nordiske Udkast, Årg. 26, n, 3-31.

Holzkamp, K. (2013). Basic Concepts of critical psychology. In Osterkamp, U. \& Schraube, E. (Eds.), Psychology from the standpoint of the subject (19- 27) Palgrave Macmillian. London.

Justitsministeriet (2018). Lov om bekæmpelse af ungdomskriminalitet. nr 1705 af 27/12/2018

Knudsen, S. J (2009). At komme Jens i møde: eksistenspsykologisk perspektiv på intervention I Bro, K., Løw, O., \& Svanholt, J. A. (2009). Psykologiske perspektiver på intervention i pædagogiske kontekster. København: Dansk Psykologisk Forlag.

Kildedal, K., Krogstrup, K (2015). Evidensbaserede Koncepters Betydning I Erlandsen, T., Jensen, R, N., Langager, S., Petersen, E, K. (2015) Udsatte Børn og Unge - en grundbog. Hans Reitzels Forlag.

Kyvsgaard, B. (1998). Den kriminelle karriere. Kbh.: Jurist- og Økonomforbundet. Leavitt, H. J. (1965). Applied organisational change in industry: Structural, technological and humanistic approaches. In J. G. March (Ed.), Handbook of organisation. Rand McNally and Company. Chicago, Illinois.

Larsen, P (21.12.2018). Børnerådet er bekymret over indførelsen af flere magtmidler over for anbragte børn og unge. Høring over bekendtgørelse om voksenansvar for anbragte børn og unge. https://www.boerneraadet.dk/hoeringssvar/hoeringssvar-2018/boerneraadet-er-bekymret-over-indfoerelsen-af-flere-magtmidler-over-for-anbragte-boern-og-unge

Lave, Jean \& Etienne Wenger (2003). Situeret læring - og andre tekster ; på dansk ved Bjørn Nake; dansk forord af Steinar Kvale. Kbh. : Hans Reitzel.

Leavitt, H. J. (1965). Applied organisational change in industry: Structural, technological and humanistic approaches. In J. G. March (Ed.), Handbook of organisation. Rand McNally and Company. Chicago, Illinois.

McKellar, A., \& Andrew, K. (2013). Key Working and the quality of relationships in secure accommodation. Scottish Journal of Residential Child Care, 12(1), 46-57.

Mottelson, M (2007) Pædagogik som teori, kunst, kald, håndværk, profession eller videnskab I Andersen, P. Ø., \& Ellegaard, T. (red.) (2012). Klassisk og moderne pædagogisk teori. (2. udg.) København: Hans Reitzels Forlag.

Nissen, M (2006). Pædagogisk psykologi - et bud på en positiv bestemmelse I Elle, B., Nielsen, K., Nissen, M (2006). Pædagogisk Psykologi - positioner og perspektiver. Roskilde Universitetsforlag. 
Oestrich, I. H (2009). Det er tanken, der tæller: kognitivt perspektiv på intervention I Bro, K., Løw, O., \& Svanholt, J. A. (2009). Psykologiske perspektiver på intervention i pædagogiske kontekster. København: Dansk Psykologisk Forlag.

Ollmann, B. (2015). Marxism and the philosophy of internal relations; or, how to replace the mysterious paradox with contradictions that can be studied and resolved. Capital and Class, 39 (1), $7-23$.

Pedersen, C (2016). Om Dømmekraften. København. Akademisk Forlag.

Pedersen, C (2017). At give kraft til dømmekraften. Social Kritik, 29(152), 20- 23.

Pollack, S. (2009). "You Cant Have It Both Ways". Punishment and Treatment of Imprisoned Women. Journal of Progressive Human Services, 20(2), 12-28.

Rose, J. (2002). Working with young people in secure accommodation : from chaos to culture. East Sussex: Routledge.

Smith, M. \& Milligan, I. (2004). The expansion of secure accommodation in Scotland: In the best interests of the child? Youth Justice, 4(3), 178-191.

Schwartz, I. (2014). Hverdagsliv og Livsforløb - Tværprofessionelt Samarbejde om Støtte til Børn og Unges Livsførelse. Århus: KLIM.

Øgendahl, C (2000). Socialpædagogernes Historie. Socialpædagogernes Landsforbund og Claus Øgendahl. Odense. 